(c) American Dairy Science Association, 2007.

\title{
Valuation of Milk Composition and Genotype in Cheddar Cheese Production Using an Optimization Model of Cheese and Whey Production
}

\author{
H. A. Johnson, L. Parvin, I. Garnett, ${ }^{1}$ E. J. DePeters, J. F. Medrano, and J. G. Fadel ${ }^{2}$ \\ Animal Science Department, University of California, Davis 95616
}

\begin{abstract}
A mass balance optimization model was developed to determine the value of the $\kappa$-casein genotype and milk composition in Cheddar cheese and whey production. Inputs were milk, nonfat dry milk, cream, condensed skim milk, and starter and salt. The products produced were Cheddar cheese, fat-reduced whey, cream, whey cream, casein fines, demineralized whey, 34\% dried whey protein, $80 \%$ dried whey protein, lactose powder, and cow feed. The costs and prices used were based on market data from March 2004 and affected the results. Inputs were separated into components consisting of whey protein, ash, casein, fat, water, and lactose and were then distributed to products through specific constraints and retention equations. A unique 2-step optimization procedure was developed to ensure that the final composition of fat-reduced whey was correct. The model was evaluated for milk compositions ranging from 1.62 to $3.59 \%$ casein, 0.41 to $1.14 \%$ whey protein, 1.89 to $5.97 \%$ fat, and 4.06 to $5.64 \%$ lactose. The $\kappa$ casein genotype was represented by different retentions of milk components in Cheddar cheese and ranged from 0.715 to $0.7411 \mathrm{~kg}$ of casein in cheese $/ \mathrm{kg}$ of casein in milk and from 0.7795 to $0.9210 \mathrm{~kg}$ of fat in cheese $/ \mathrm{kg}$ of fat in milk. Milk composition had a greater effect on Cheddar cheese production and profit than did genotype. Cheese production was significantly different and ranged from $9,846 \mathrm{~kg}$ with a high-casein milk composition to $6,834 \mathrm{~kg}$ with a high-fat milk composition per $100,000 \mathrm{~kg}$ of milk. Profit (per 100,000 kg of milk) was significantly different, ranging from $\$ 70,586$ for a highfat milk composition to $\$ 16,490$ for a low-fat milk composition. However, cheese production was not significantly different, and profit was significant only for the lowest profit $(\$ 40,602)$ with the $\kappa$-casein genotype. Results from this model analysis showed that the optimization model is useful for determining costs and prices
\end{abstract}

Received March 24, 2006.

Accepted September 6, 2006.

${ }^{1}$ In memory of Ian Garnett-a valued friend and colleague.

${ }^{2}$ Corresponding author: jgfadel@ucdavis.edu for cheese plant inputs and products, and that it can be used to evaluate the economic value of milk components to optimize cheese plant profits.

Key words: cheese yield prediction, $\kappa$-casein, milk fat, optimization model

\section{INTRODUCTION}

Reducing production costs is an important contribution to increasing profitability. An important factor influencing production costs is the yield of cheese from a quantity of milk. Increasing the yield will positively influence both fixed costs and the cost of goods per unit of product. To evaluate the net economic benefit of increasing the frequency of an allele (A or B for $\kappa$-CN) before embarking on a breeding program, a linear program was created to determine the optimal contribution of various inputs to maximize profit. The objectives of this study were to develop a mass balance linear program to estimate cheese, whey, and whey product yields for different milk compositions and $\kappa$-CN genotypes and to evaluate the dollar value of milk fat, milk protein, and the $\kappa$-CN genotype to the cheese-production facility. The model evaluates the effects of milk composition and genotype ( $\kappa$-CN AA or BB) on cheese yield.

The genetic variants of the milk protein $\kappa$-CN have been shown to have an important influence on the composition and cheese-making properties of milk (Feagan, 1979; Schaar, 1985; Aleandri et al., 1990; Ng-KwaiHang, 1993; Tong et al., 1994). A significant positive effect on cheese yield has been reported for different genotypes of the proteins (Marziali and Ng-Kwai-Hang, 1986; Aleandri et al., 1990; Ng-Kwai-Hang, 1993; Tong et al., 1994), where the increase in cheese yield ranged from 2 for the $\kappa$-CN AA allele to about $8 \%$ for the $\kappa$ $\mathrm{CN}$ BB allele. Because cows can be genotyped for these proteins by DNA analysis of either a blood or a milk sample, the opportunity exists to breed for a future milk supply that possesses superior manufacturing properties.

\section{General Description of the Model}

The model plant was an integrated manufacturer capable of producing several products, including Cheddar cheese, cream, fat-reduced whey, whey cream, deminer- 


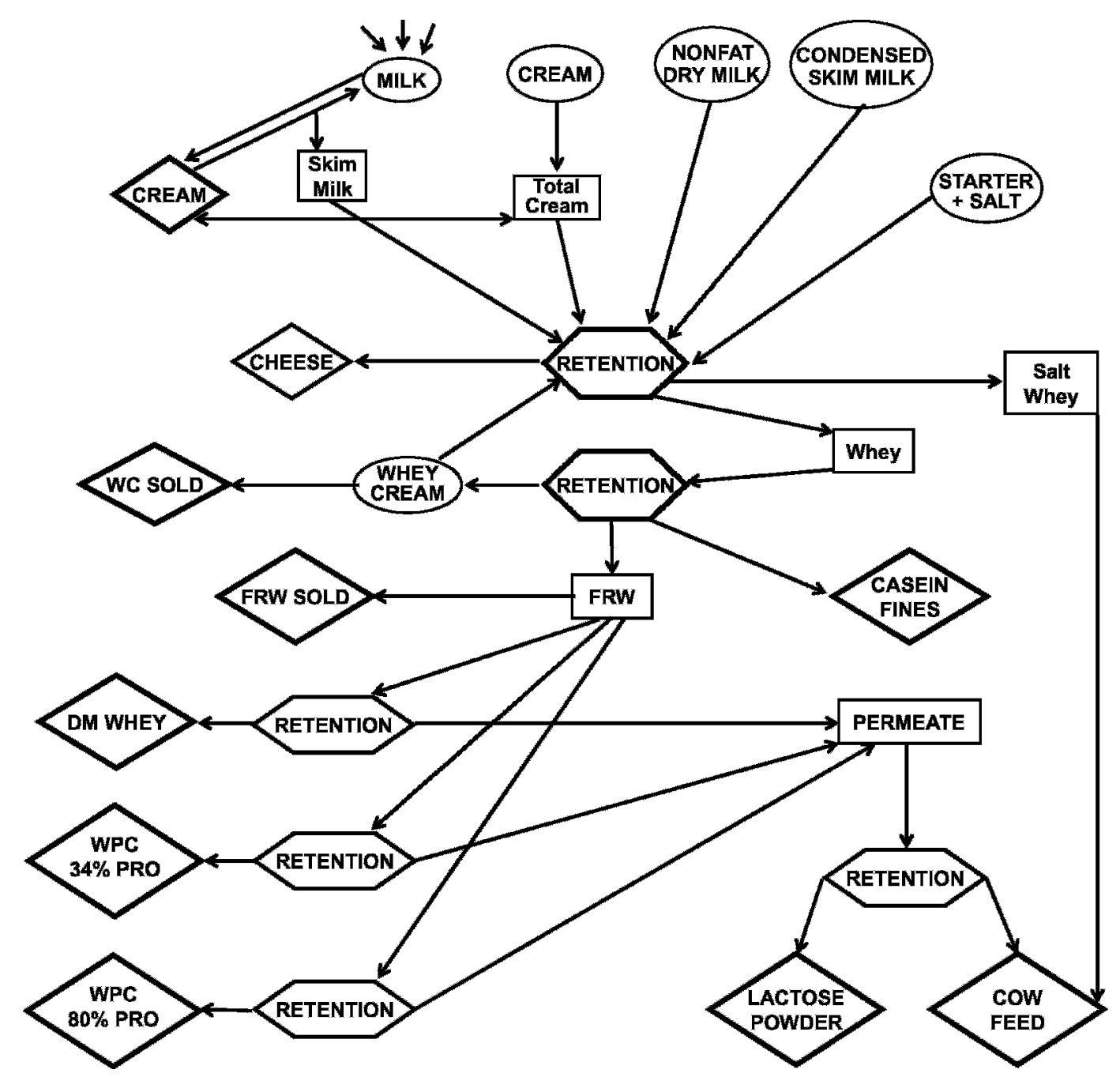

Figure 1. Flow of milk and milk products to cheese and whey products. Ovals are inputs into the cheese-making process; hexagons are retentions; rectangles are intermediates; diamonds are final products sold. $\mathrm{WC}=$ Whey cream; $\mathrm{FRW}=$ fat-reduced whey; $\mathrm{DM}=$ demineralized; $\mathrm{WPC}=$ whey protein concentrate; $\mathrm{PRO}=$ protein $; \mathrm{WPC} 34 \% \mathrm{PRO}=$ whey protein concentrate $34 \%$ protein; $\mathrm{WPC} 80 \% \mathrm{PRO}=$ whey protein concentrate $80 \%$ protein.

alized whey, whey protein concentrates at 34 and $80 \%$ protein, lactose powder, CN fines, and cow feed. Depending on the price and costs of cream, cream can be skimmed from milk and sold, or it can be bought to increase Cheddar cheese production. Whey cream produced from reducing whey to fat-reduced whey can also be sold or recycled back into cheese production. Figure 1 shows a flow diagram of inputs, intermediate products, and output products. Retentions are the proportion of inputs retained in a product and can vary with the plant and the genotype of the cow producing the milk. Permeate refers to the leftover components after products have been made. Lactose powder and cow feed are produced from permeate. However, because compositions and prices were difficult to obtain for lactose pow- der and cow feed, the results relating to their production are not discussed.

Based on the model plant, a single-period linear programming model was developed using general algebraic modeling (GAMS) system software (Brooke et al., 1998) with BDMLP (Brooke, Drud, and Meeraus linear program) as the solver. The BDMLP solver is a linear program and mixed integer program solver that is provided with the GAMS system. The model tracks 6 milk components (whey protein, CN, fat, lactose, ash, and water) of each input (milk, cream, NDM, condensed skim milk, and starter and salt) and allocates them to intermediate and final products based on retention rates and economic values. Plant capacity was 100,000 $\mathrm{kg}$ of milk daily. 
The purchase and replacement of capital equipment required to operate a cheese plant as well as fixed operating costs, such as salaries, repairs, insurance, energy to operate equipment, and taxes, were not taken into account in the model because they are constant across milk composition and retentions. Seasonal variation in milk properties was also not considered. The time frame of the model was one day. Because NPN was a minimal part of whey and whey by-products, it was combined with and considered part of the whey protein component. The lactic acid content of the whey and whey by-products was included in the lactose component.

\section{Objective Functions}

The model was developed and solved in 2 parts to maximize profit from products sold. The sole purpose of the first part of the model was to determine the fatreduced whey composition that was used in the second part of the model as a composition constraint, but not as a quantity constraint, for fat-reduced whey (Figure 1). Thus, in part 2 the quantities of products purchased, sold, or both were independent of the results from part 1 . The objective function in part 1 (equation [1]) maximizes profit (PROFIT1) from producing Cheddar cheese (Cheese), from cream sold (CRS), whey cream sold (WCS), fat-reduced whey (FRW) sold (FRWS), and CN fines sold (CNF) over the cost of the inputs milk, condensed skim milk (CSM), NDM, and cream bought (CRB). Inputs and products were described on a component basis represented by I = (whey protein, ash, CN, fat, water, and lactose):

$$
\begin{gathered}
\text { PROFIT1 }=(\text { Cheese } \times \text { PriceCheese }) \\
+(\text { CRS } \times \text { PriceCRS })+(\text { WCS } \times \text { PriceWCS }) \\
+(\text { FRW } \times \text { PriceFRWS })+(\mathrm{CNF} \times \text { PriceCNF }) \\
-(\text { Milk } \times \text { CostMilk })-(\mathrm{CSM} \times \text { CostCSM }) \\
-(\mathrm{NDM} \times \text { CostNDM })-(\text { CRB } \times \text { CostCRB }) .
\end{gathered}
$$

The objective function from part 2 (equation [2]) maximized profit (PROFIT2) from overall costs and revenues for all inputs (milk, CSM, NDM, and CRB) and products, including cheese, CRS, WCS, FRWS, CNF, demineralized whey (DMW), 34\% whey protein concentrate (D34), 80\% whey protein concentrate (D80), lactose powder (LP), and leftover permeate sold as cow feed $(\mathrm{CF})$ :

$$
\begin{gathered}
\text { PROFIT2 }=(\text { Cheese } \times \text { PriceCheese }) \\
+(\text { CRS } \times \text { PriceCRS })+(\text { WCS } \times \text { PriceWCS })
\end{gathered}
$$

$$
\begin{gathered}
+(\text { FRWS } \times \text { PriceFRWS })+(\text { DMW } \times \text { PriceDMW }) \\
+(\text { D34 } \times \text { PriceD34 })+(\text { D } 80 \times \text { PriceD } 80) \\
+(\mathrm{CNF} \times \text { PriceCNF })+(\text { LP } \times \text { PriceLactose }) \\
+(\mathrm{CF} \times \text { PriceCowFeed })-(\text { Milk } \times \text { CostMilk }) \\
-(\mathrm{CSM} \times \text { CostCSM })-(\mathrm{NDM} \times \text { CostNDM }) \\
-(\mathrm{CRB} \times \text { CostCRB }) .
\end{gathered}
$$

The costs of inputs and prices of products are listed in Table 1.

\section{Constraint Equations}

Equations constrained the composition of products, limited retentions of an input component into a product, and balanced inputs to sum to products (Table 2). Constraints on the composition of Cheddar cheese were based on legal limits by FDA Federal Standards of Identity (US Department of Health and Human Services, FDA, 1998) for water in cheese, and maximum CN-tofat ratios in cheese (equations [42] to [47]). Constraints on water and fat in whey cream (equations [57] to [69]) and water, protein, ash, fat, and lactose in demineralized whey, $34 \%$ whey protein concentrate, and $80 \%$ whey protein concentrate (equations [80] to [109]) were based on minimum standard compositions of the products.

Balance equations ensured that components from an input equaled components in product(s). In the model, milk, cream, NDM, condensed skim milk, whey cream, and starter and salt components sum to components in cheese, salt whey, and whey, as found in Table 2, equations [43], [48], and [49]. Whey components sum to components in fat-reduced whey, whey cream, and CN fines (Table 2, equation [56]), and fat-reduced whey components sum to components in demineralized whey, $34 \%$ whey protein concentrate, and $80 \%$ whey protein concentrate and their respective permeates, as described in Table 2, equations [76], [80], [91], and [101]).

\section{Compositions}

All inputs and products were broken into component compositions of whey protein (mostly albumin), ash, $\mathrm{CN}$, fat, water, and lactose, represented by subscript I in the equations. Standard compositions were used for condensed skim milk, NDM, cream, and starter and salt (Table 3). Milk compositions were based on data collected over $3 \mathrm{yr}$ (2000 to 2002) from the University of California-Davis dairy herd. Milk CP, CN, fat, and lactose were determined by standard methods (methods 972.16 and 998.06; AOAC, 2002). For the purposes of 
Table 1. Definition of terms in the objective functions

\begin{tabular}{|c|c|c|}
\hline Decision variable & Definition & Value \\
\hline Cheese & Cheddar cheese produced & $\mathrm{kg}$ \\
\hline PriceCheese & Price of cheese & $\$ 3.02 / \mathrm{kg}^{1}$ \\
\hline CRS & Cream sold & $\mathrm{kg}$ \\
\hline PriceCRS & Price of cream & $\$ 4.16 / \mathrm{kg}^{2}$ \\
\hline WCS & Whey cream sold & $\mathrm{kg}$ \\
\hline PriceWCS & Price of whey cream sold & $\$ 1.74 / \mathrm{kg}^{3}$ \\
\hline FRW & Fat-reduced whey sold (part 1 of the model) & $\mathrm{kg}$ \\
\hline FRWS & Fat-reduced whey sold (part 2 of the model) & $\mathrm{kg}$ \\
\hline PriceFRWS & Price of fat-reduced whey sold & $\$ 0.36 / \mathrm{kg}^{1}$ \\
\hline DMW & Demineralized whey & $\mathrm{kg}$ \\
\hline PriceDMW & Price of demineralized whey & $\$ 1.25 / \mathrm{kg}^{4}$ \\
\hline D34 & $34 \%$ whey protein concentrate & $\mathrm{kg}$ \\
\hline PriceD34 & Price of $34 \%$ whey protein concentrate & $\$ 1.61 / \mathrm{kg}^{5}$ \\
\hline D80 & $80 \%$ whey protein concentrate & $\mathrm{kg}$ \\
\hline PriceD80 & Price of $80 \%$ whey protein concentrate & $\$ 4.74 / \mathrm{kg}^{6}$ \\
\hline $\mathrm{CNF}$ & $\mathrm{CN}$ fines & $\mathrm{kg}$ \\
\hline PriceCNF & Price of $\mathrm{CN}$ fines & $\$ 0 / \mathrm{kg}^{4}$ \\
\hline LP & Lactose powder & $\mathrm{kg}$ \\
\hline PriceLactose & Price of lactose powder & $\$ 1.74 / \mathrm{kg}^{4}$ \\
\hline $\mathrm{CF}$ & Cow feed (permeate) sold & $\mathrm{kg}$ \\
\hline PriceCowFeed & Price of cow feed (permeate) sold & $\$ 0.024 / \mathrm{kg}^{4}$ \\
\hline Milk & Milk & $100,000 \mathrm{~kg}$ \\
\hline CostMilk & Cost of milk & $\$ 0.26 / \mathrm{kg}^{1}$ \\
\hline CSM & Condensed skim milk & $\mathrm{kg}$ \\
\hline CostCSM & Cost of condensed skim milk & $\$ 1.92 / \mathrm{kg}^{2}$ \\
\hline NDM & Nonfat dry milk & $\mathrm{kg}$ \\
\hline CostNDM & Cost of nonfat dry milk & $\$ 1.77 / \mathrm{kg}^{1}$ \\
\hline $\mathrm{CRB}$ & Cream bought & $\mathrm{kg}$ \\
\hline CostCRB & Cost of cream bought & $\$ 4.16 / \mathrm{kg}^{2}$ \\
\hline \multicolumn{3}{|c|}{${ }^{1}$ From CDFA (2004). } \\
\hline \multicolumn{3}{|c|}{${ }^{2}$ From USDA (2004). } \\
\hline \multicolumn{3}{|c|}{$\begin{array}{l}{ }^{3} \text { Price based on fat content. Fat value at the price of AA butter from CDFA (1998), then the multiplier } \\
\text { of } 1.1 \text { (A. DeRooy, Hilmar Cheese Co., Hilmar, CA; personal communication, June 23, 1998) was used to } \\
\text { convert to the whey cream price. }\end{array}$} \\
\hline \multicolumn{3}{|c|}{$\begin{array}{l}{ }^{4} \text { Mullinax, D. (Hilmar } \\
{ }^{5} \text { From USDA (2000). }\end{array}$} \\
\hline${ }^{6} \mathrm{C}$. Curran (USI & ion, Dec. 7,2000$)$. & \\
\hline
\end{tabular}

this paper, whey protein was determined as milk CP minus CN. Ash was determined from data (Zadow, 1992) that included composition changes over $12 \mathrm{mo}$. Whey protein, CN, fat, and lactose were varied individually based on high and low values from the University of California-Davis data set for 11 different milk compositions, as listed in Table 4.

\section{Retentions}

Minimum and maximum limits on retentions constrained the amount of component from an input that could appear in a product. Retention constraints were used for milk components to cheese and whey, whey components to fat-reduced whey and whey cream, and permeate components to lactose powder. Values for retention minimum and maximum equations milk to whey, whey to whey cream, whey to fat-reduced whey, and permeate to lactose powder retentions were calculated from estimating the proportion of each component that ended up in product using standard product compositions (Table 5). Retentions of milk components to cheese were based on data from Schaar (1985) and Walsh et al. (1995) on changes in protein and fat retentions attributable to either the $\kappa$-CN AA genotype or the $\kappa$-CN BB genotype (Table 6 ). Because protein retention of milk to cheese in the model was composed of a whey protein fraction and a CN fraction, the whey protein fraction of the retention was assumed fixed at 3.4\% and the $\mathrm{CN}$ fraction of the retention made up the difference. Ten different sets of milk to cheese retentions were used (Table 7).

\section{Sensitivity Analysis and Statistical Analysis}

To assess the effects of different milk compositions and retentions on cheese and whey production and profit, 110 simulations were run, including all combinations of milk compositions and cheese retentions. Eleven different milk compositions (Table 4) and 10 
Table 2. Constraint equations of the Cheddar cheese plant model ${ }^{1}$

Part 1 -Cheese production

Milk

Amount of milk purchased (MILK)

Amount of components in milk (MILK $)$

Amount of components in skim milk (SMILK $)_{\mathrm{I}}$ ) after

subtracting cream components from milk $\left(\mathrm{CRM}_{\mathrm{I}}\right)$

Minimum components from SMILK to cheese $^{3}$

Maximum components from SMILK to cheese ${ }^{3}$

Minimum components from SMILK to whey ${ }^{3}$

Maximum components from SMILK to whey ${ }^{3}$

SMILK (M) components to cheese, whey, and salt whey $\left(\mathrm{SW}_{\mathrm{I}}\right)$

Cream (CR)

CR bought (CRB)

CR sold (CRS)

Amount of components in $\mathrm{CR}$ from milk $\left(\mathrm{CRM}_{\mathrm{I}}\right)$

Amount of components in $\mathrm{CRB}\left(\mathrm{CRB}_{\mathrm{I}}\right)$

Amount of components in CRS $\left(\mathrm{CRS}_{\mathrm{I}}\right)$

Minimum components from CR to cheese ${ }^{3}$

Maximum components from CR to cheese ${ }^{3}$

Minimum components from CR to whey $^{3}$

Maximum components from CR to whey ${ }^{3}$

CR components from milk (CRM) and CRB minus CRS

Cream components into cheese, whey, and SW

NDM

NDM purchased (NDM)

Amount of components in NDM $\left(\mathrm{NDM}_{\mathrm{I}}\right)$ purchased

Minimum components from NDM to cheese $^{3}$

Maximum components from NDM to cheese ${ }^{3}$

Minimum components from NDM to whey ${ }^{3}$

Maximum components from NDM to whey ${ }^{3}$

NDM components into cheese, whey, and SW

Condensed skim milk (CSM)

CSM purchased (CSM)

Amount of components in $\operatorname{CSM}\left(\mathrm{CSM}_{\mathrm{I}}\right)$

Minimum components from CSM to cheese ${ }^{3}$

Maximum components from CSM to cheese ${ }^{3}$

Minimum components from CSM to whey ${ }^{3}$

Maximum components from CSM to whey ${ }^{3}$

CSM components into cheese, whey, and SW

Starter and salt (SS)

Amount of components in $\mathrm{SS}\left(\mathrm{SS}_{\mathrm{I}}\right)$ is a fixed proportion of total inputs [SMILK, CR, NDM, CSM, WC

(whey cream)]

Minimum components from SS to cheese ${ }^{3}$

Maximum components from SS to cheese $^{3}$

Minimum components from SS to whey ${ }^{3}$

Maximum components from SS to whey ${ }^{3}$

SS components into cheese, whey, and SW

Cheese

Cheese sold (Cheese)

Amount of components in cheese is the sum of input

components based on retentions for each input component

Water less than $38 \%$ of cheese

Fat in cheese greater than $50 \%$ (dry basis)

CN-to-fat ratio in cheese greater than $64 \%$

CN-to-fat ratio in cheese less than $80 \%$

Salt whey (SW)

Amount of components in $\mathrm{SW}\left(\mathrm{SW}_{\mathrm{I}}\right)$ is the sum of input

component compositions based on retentions

Whey

Amount of components in whey is the sum of input component compositions based on retentions

Minimum components from whey to fat-reduced whey $(\mathrm{FRW})^{3}$

Maximum components from whey to $\mathrm{FRW}^{3}$ $\begin{array}{lr}\text { MILK }<100,000 & 3 \\ \text { MILK }_{\mathrm{I}}{ }^{2}=\text { MILK } \times \text { PercentMILK }_{\mathrm{I}} & 4 \\ \text { SMILK }_{\mathrm{I}}=\text { MILK }_{\mathrm{I}}-\mathrm{CRM}_{\mathrm{I}} & 5 \\ & \\ \text { MCheese }_{\mathrm{I}}>\text { MinCheese }_{\mathrm{I}} \times \text { SMILK }_{\mathrm{I}} & 6 \\ \text { MCheese }_{\mathrm{I}}<\text { MaxCheese }_{\mathrm{I}} \times \text { SMILK }_{\mathrm{I}} & 7 \\ \text { MWhey }_{\mathrm{I}}>\text { MinWhey }_{\mathrm{I}} \times \text { SMILK }_{\mathrm{I}} & 8 \\ \text { MWhey }_{\mathrm{I}}<\text { MaxWhey }_{\mathrm{I}} \times \text { SMILK }_{\mathrm{I}} & 9 \\ \text { SMILK }_{\mathrm{I}}=\text { MCheese }_{\mathrm{I}}+\text { MWhey }_{\mathrm{I}}+\mathrm{MSW}_{\mathrm{I}} & 10\end{array}$

$\mathrm{CRB}=\Sigma_{\mathrm{I}} \mathrm{CRB}_{\mathrm{I}}$

$\mathrm{CRS}=\Sigma_{\mathrm{I}} \mathrm{CRS}_{\mathrm{I}}$

$\mathrm{CRM}_{\mathrm{I}}=\left(\Sigma_{\mathrm{I}} \mathrm{CRM}_{\mathrm{I}}\right) \times$ PercentCR $_{\mathrm{I}}$

$\mathrm{CRB}_{\mathrm{I}}=\mathrm{CRB} \times$ PercentCR $_{\mathrm{I}}$

$\mathrm{CRS}_{\mathrm{I}}=\mathrm{CRS} \times$ PercentCR $_{\mathrm{I}}$

CRCheese $_{\mathrm{I}}>$ MinCheese $_{\mathrm{I}} \times \mathrm{CR}_{\mathrm{I}} \quad 16$

CRCheese $_{\mathrm{I}}<$ MaxCheese $_{\mathrm{I}} \times \mathrm{CR}_{\mathrm{I}} \quad 17$

CRWhey $_{\text {I }}>$ MinWhey $_{\text {I }} \times$ CR $_{\text {I }} \quad 18$

CRWhey $_{\text {I }}<$ MaxWhey $\times \mathrm{CR}_{\mathrm{I}} \quad 19$

$\mathrm{CR}_{\mathrm{I}}=\mathrm{CRM}_{\mathrm{I}}+\mathrm{CRB}_{\mathrm{I}}-\mathrm{CRS}_{\mathrm{I}}$

$\mathrm{CR}_{\mathrm{I}}=$ CRCheese $_{\mathrm{I}}+\mathrm{CRWhey}_{\mathrm{I}}+\mathrm{CRSW}_{\mathrm{I}}$

$\mathrm{NDM}=\Sigma_{\mathrm{I}} \mathrm{NDM}_{\mathrm{I}}$

$\mathrm{NDM}_{\mathrm{I}}=\mathrm{NDM} \times$ PercentNDM $_{\mathrm{I}}$

NDMCheese $_{\mathrm{I}}>$ MinCheese $_{\mathrm{I}} \times \mathrm{NDM}_{\mathrm{I}}$

NDMCheese $_{\mathrm{I}}<$ MaxCheese $_{\mathrm{I}} \times \mathrm{NDM}_{\mathrm{I}}$

NDMWhey $_{\text {I }}>$ MinWhey $_{\text {I }} \times$ NDM $_{\text {I }}$

NDMWhey $_{I}<$ MaxWhey $_{I} \times$ NDM $_{I}$

$\mathrm{NDM}_{\mathrm{I}}=\mathrm{NDMCheese}_{\mathrm{I}}+\mathrm{NDMWhey}_{\mathrm{I}}+\mathrm{NDMSW}_{\mathrm{I}}$

$\mathrm{CSM}=\Sigma_{\mathrm{I}} \mathrm{CSM}_{\mathrm{I}}$

$\mathrm{CSM}_{\mathrm{I}}=\mathrm{CSM} \times$ PercentCSM $_{\mathrm{I}}$

CSMCheese $_{\mathrm{I}}>$ MinCheese $_{\mathrm{I}} \times \mathrm{CSM}_{\mathrm{I}}$

CSMCheese $_{I}<$ MaxCheese $_{I} \times$ CSM $_{I}$

CSMWhey I $_{I}>$ MinWhey $_{I} \times$ CSM $_{I}$

CSMWhey $_{\mathrm{I}}<$ MaxWhey $_{\mathrm{I}} \times \mathrm{CSM}_{\mathrm{I}}$

$\mathrm{CSM}_{\mathrm{I}}=$ CSMCheese $_{\mathrm{I}}+\mathrm{CSMWhey}_{\mathrm{I}}+\mathrm{CSMSW}_{\mathrm{I}}$

$\mathrm{SS}_{\mathrm{I}}=\Sigma_{\mathrm{I}}\left(\mathrm{SMILK}_{\mathrm{I}}+\mathrm{CR}_{\mathrm{I}}+\mathrm{NDM}_{\mathrm{I}}+\mathrm{CSM}_{\mathrm{I}}+\mathrm{WC}_{\mathrm{I}}\right)$

$\times$ PercentSS $_{\text {I }}$

SSCheese $_{\mathrm{I}}>$ MinCheese $_{\mathrm{I}} \times \mathrm{SS}_{\mathrm{I}}$

SSCheese $_{\mathrm{I}}<$ MaxCheese $_{\mathrm{I}} \times \mathrm{SS}_{\mathrm{I}}$

SSWhey $_{I}>$ MinWhey $_{I} \times$ SS $_{\text {I }}$

SSWhey $_{\mathrm{I}}<$ MaxWhey $_{\mathrm{I}} \times \mathrm{SS}_{\mathrm{I}}$

$\mathrm{SS}_{\mathrm{I}}=\mathrm{SSCheese}_{\mathrm{I}}+\mathrm{SSWhey}_{\mathrm{I}}+\mathrm{SSSW}_{\mathrm{I}}$

(1)

29

30

33

Cheese $=\Sigma_{\mathrm{I}}$ Cheese $_{\mathrm{I}}$

+ CSMCheese $_{\mathrm{I}}+$ SSCheese $_{\mathrm{I}}+$ WCCheese $\left._{\mathrm{I}}\right)$
Cheese $_{\text {Water }}<0.38 \times \Sigma_{\mathrm{I}}$ Cheese $_{\mathrm{I}}$

Cheese $_{\text {Fat }}>0.5 \times\left(\right.$ Cheese - Cheese $\left._{\text {Water }}\right)$

Cheese $_{\mathrm{CN}}>0.64 \times$ Cheese $_{\mathrm{Fat}} \quad 46$

Cheese $_{\mathrm{CN}}<0.80 \times$ Cheese $_{\text {Fat }} \quad 47$

$\mathrm{SW}_{\mathrm{I}}=\mathrm{MSW}_{\mathrm{I}}+\mathrm{CRSW}_{\mathrm{I}}+\mathrm{NDMSW}_{\mathrm{I}}+\mathrm{CSMSW}_{\mathrm{I}}$

$+\mathrm{SSSW}_{\mathrm{I}}+\mathrm{WCSW}_{\mathrm{I}}$

Whey $=$ MWhey $_{I}+$ CRWhey $_{I}+$ NDMWhey $_{I} \quad 49$

+ CSMWhey $_{I}+$ SSWhey $_{I}+$ WCWhey $_{I}$

WheyFRW $_{\text {I }}>$ MinFRW $_{\text {I }} \times$ Whey $_{\text {I }}$

WheyFRW $_{\text {I }}<$ MaxFRW $_{\text {I }} \times$ Whey $_{\text {I }}$

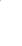

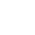


Table 2 (Continued). Constraint equations of the Cheddar cheese plant model ${ }^{1}$

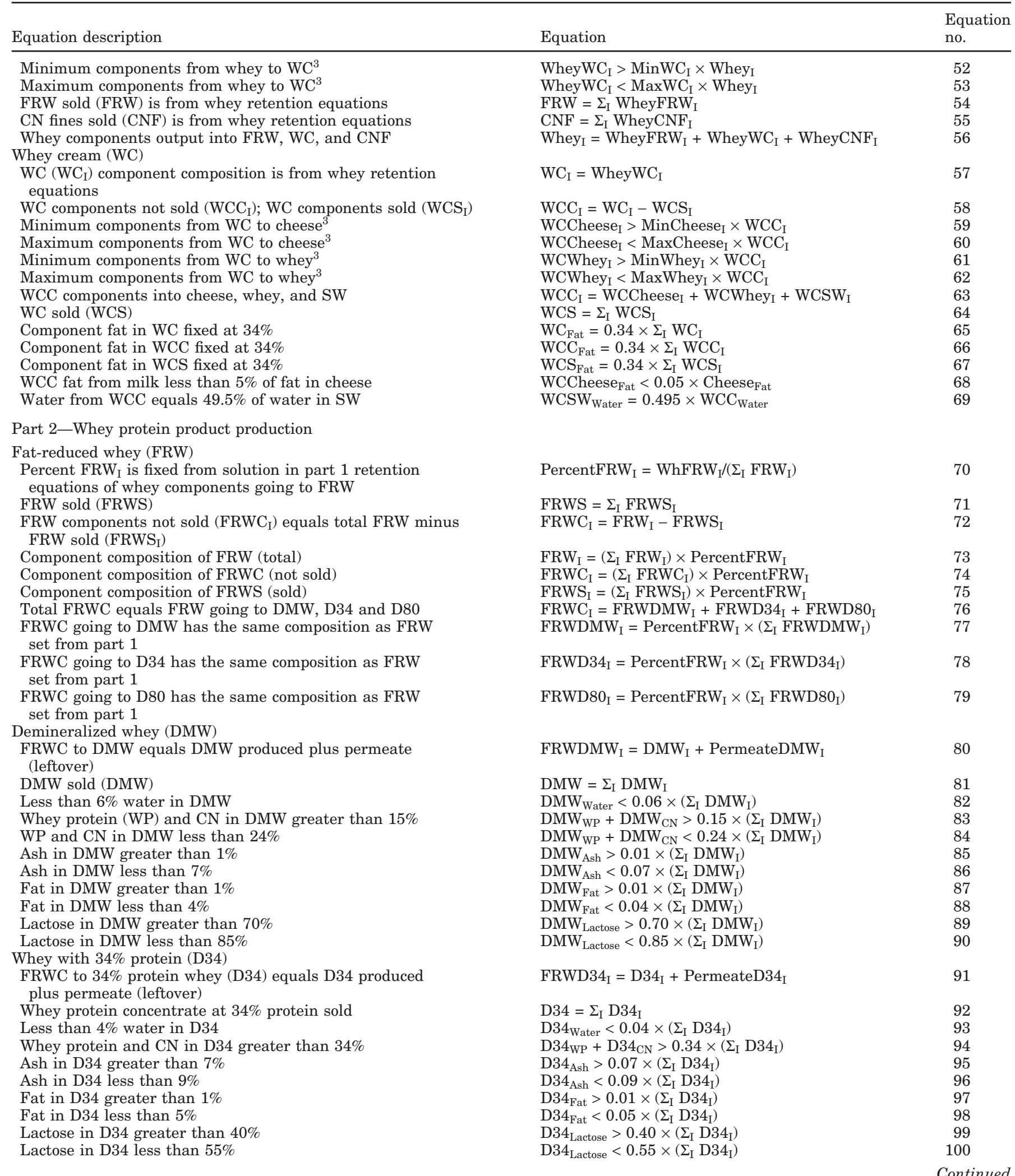


Table 2 (Continued). Constraint equations of the Cheddar cheese plant model ${ }^{1}$

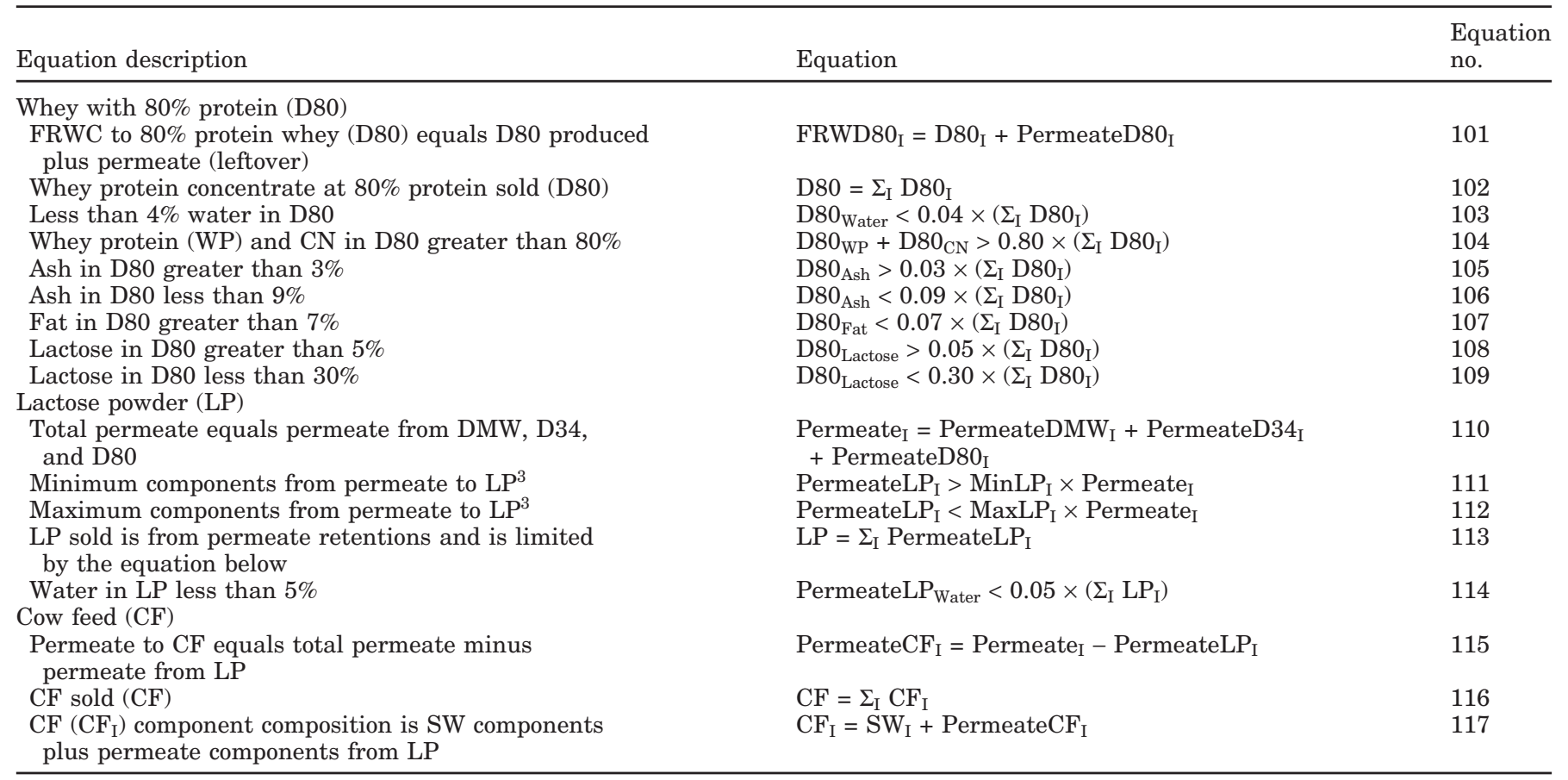

${ }^{1}$ Units are in kilograms unless otherwise noted.

${ }^{2}$ Index I represents the composition of inputs and products as (whey protein, ash, CN, fat, water, and lactose); therefore, each equation indexed by I represents 6 equations, one for each component.

${ }^{3}$ Retention equations limiting the minimum and maximum components (I) transferred to each product.

sets of retentions on cheese (Table 7) were assumed to represent milk of different genotypes because a particular milk genotype might contribute more to profit than another genotype, depending on which products a cheese plant produces. The retentions described in Table 5 were fixed for all simulations.

Separate runs were done for each simulation if NDM or cream bought were not purchased or if demineralized whey, $34 \%$ whey protein concentrate, or $80 \%$ whey protein concentrate were not produced. The cost of NDM or cream bought and the prices for demineralized whey,

Table 3. Standard composition of input ingredients

\begin{tabular}{|c|c|c|c|c|}
\hline Component & $\mathrm{CSM},{ }^{1} \%$ & $\mathrm{NDM}^{2} \%$ & $\mathrm{CR},{ }^{3} \%$ & $\mathrm{SS},{ }^{4} \%$ \\
\hline $\mathrm{WP}^{5}$ & 1.67 & 6.57 & 0.54 & 5.00 \\
\hline Ash & 2.30 & 7.98 & 0.58 & 1.70 \\
\hline $\mathrm{CN}$ & 8.13 & 29.47 & 2.14 & 0.00 \\
\hline Fat & 0.30 & 0.90 & 30.08 & 0.00 \\
\hline Water & 73.00 & 3.43 & 62.98 & 0.00 \\
\hline Lactose & 14.60 & 51.65 & 3.68 & 0.00 \\
\hline
\end{tabular}

${ }^{1}$ Condensed skim milk, from Wong (1988).

${ }^{2}$ Nonfat dry milk, averaged from Chandan (1997) and Wong (1988).

${ }^{3}$ Cream, from Chandan (1997).

${ }^{4}$ Starter and salt, D. Mullinax (Hilmar Cheese Company, Hilmar, CA, personal communication, Dec. 4, 2000).

${ }^{5} \mathrm{WP}=$ Whey protein.
$34 \%$ whey protein concentrate, or $80 \%$ whey protein concentrate were adjusted to determine the cost or price necessary for these products to enter the solution (Tables 10 to 14). Marginal values output by GAMS were unable to be used because there was too much interdependence between the variables. Runs for values of cream bought included the assumption that cream sold was zero (CRS $=0)$. Results of simulations for different milk compositions and milk-to-cheese retentions based on genotype were compared using the statistical model

$$
\mathrm{Y}_{\mathrm{ij}}=\mu+\alpha_{\mathrm{i}}+\beta_{\mathrm{j}}+\varepsilon_{\mathrm{ij}},
$$

where $\alpha_{\mathrm{i}}$ is the milk composition and $\mathrm{i}=1,2, \ldots 6$ (Table 4 ), and $\beta_{\mathrm{j}}$ is the genotype and $\mathrm{j}=1,2, \ldots 8$ (Table 7) using PROC GLM of SAS v. 8.1 (SAS Institute, 2002). Multiple means were compared within the main effects milk composition and genotype using least squares means comparisons.

\section{RESULTS}

The major products produced and the associated profit from the simulation results are presented in Tables 8 and 9 for different milk compositions and retentions (genotypes), respectively. The percent composi- 
Table 4. Milk compositions based on data from the University of California at Davis dairy herd

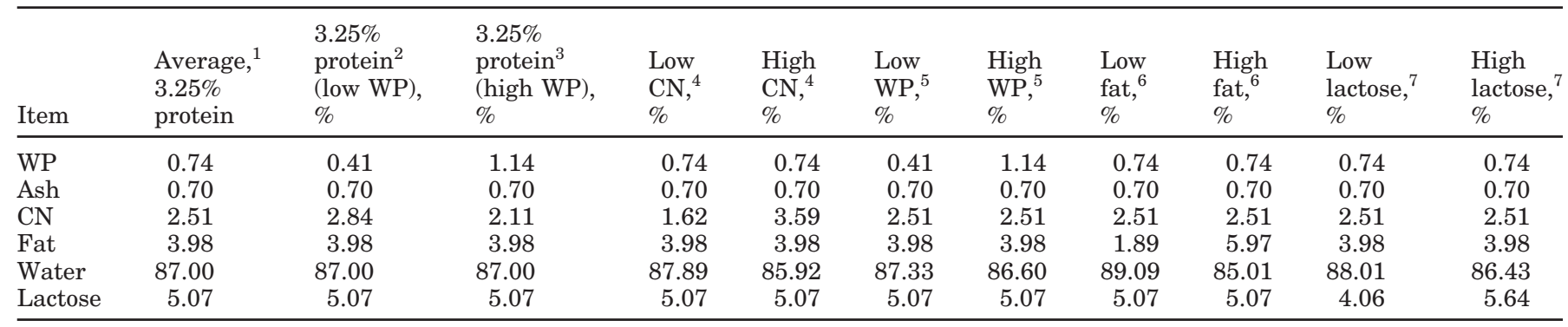

${ }^{1}$ Average composition from 1,528 cow records over 3 yr (2000 to 2002) ranging from 9 to 700 DIM.

${ }^{2}$ Lowest percentage of whey protein (WP) found in records. The percentage of CN was adjusted to $3.25 \%$ of total protein.

${ }^{3}$ Highest percentage of WP in found in records. The percentage of CN was adjusted to $3.25 \%$ of total protein.

${ }^{4}$ Highest and lowest percentages of $\mathrm{CN}$ from cow records. The percentage of WP was set at the average, so total protein varies.

${ }^{5}$ Highest and lowest percentages of WP from cow records. The percentage of CN was set at the average, so total protein varies.

${ }^{6}$ Highest and lowest percentages of fat from cow records. The percentage of water changed, so the percentage composition sums to 100 .

${ }^{7}$ Highest and lowest percentages of lactose from cow records. The percentage of water changed, so the percentage composition sums to 100 .

Table 5. Retention ranges for milk and whey components to processed products (units in kg of component/ $\mathrm{kg}$ of input)

\begin{tabular}{|c|c|c|c|c|c|c|c|c|}
\hline \multirow[b]{2}{*}{ Component } & \multicolumn{2}{|c|}{ 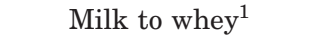 } & \multicolumn{2}{|c|}{ Whey to $\mathrm{WC}^{2}$} & \multicolumn{2}{|c|}{ Whey to FRW ${ }^{3}$} & \multicolumn{2}{|c|}{ Permeate to $\mathrm{LP}^{4}$} \\
\hline & MinWhey $_{\mathrm{I}}$ & MaxWhey $_{\text {I }}$ & $\operatorname{MinWC}_{\mathrm{I}}$ & $\mathrm{MaxWC}_{\mathrm{I}}$ & MinFRW $_{\text {I }}$ & MaxFRW $_{\text {I }}$ & $\operatorname{MinLP}_{\mathrm{I}}$ & $\operatorname{MaxLP}_{\mathrm{I}}$ \\
\hline $\mathrm{WP}^{5}$ & 0.51 & 0.51 & 0.0 & 0.0 & 0.90 & 0.90 & 0.13 & 0.15 \\
\hline Ash & 0.11 & 0.11 & 0.0 & 0.0 & 0.98 & 0.98 & 0.018 & 0.018 \\
\hline $\mathrm{CN}$ & 0.004 & 0.004 & 0.0 & 0.0 & 0.70 & 0.70 & 0.90 & 0.90 \\
\hline Fat & 0.04 & 0.04 & 0.5 & 0.75 & 0.25 & 0.25 & 0.11 & 0.11 \\
\hline Water & 0.0 & 0.95 & 0.002 & 0.005 & 0.80 & 0.995 & 0.00028 & 0.00028 \\
\hline Lactose & 0.45 & 0.45 & 0.0 & 0.0 & 0.99 & 0.99 & 0.99 & 0.99 \\
\hline
\end{tabular}

${ }^{1}$ MinWhey $_{I}$ and MaxWhey $_{I}$ are the minimum and maximum retentions for the Ith component for milk to whey and are found in Table 2 in equations [8], [18], [26], [33], [39], and [9], [19], [27], [34], and [40], respectively.

${ }^{2} \mathrm{MinWC}_{\mathrm{I}}$ and $\mathrm{MaxWC}_{\mathrm{I}}$ are the minimum and maximum retentions for the Ith component for whey to whey cream (WC) and are found in Table 2 in equations [52] and [53], respectively.

${ }^{3} \mathrm{MinFRW}_{\mathrm{I}}$ and $\mathrm{MaxFRW}_{\mathrm{I}}$ are the minimum and maximum retentions for the Ith component for whey to fat-reduced whey (FRW) and are found in Table 2 in equations [50] and [51], respectively.

${ }^{4} \mathrm{MinLP}_{\mathrm{I}}$ and $\mathrm{MaxLP}_{\mathrm{I}}$ are the minimum and maximum retentions for the Ith component for permeate to lactose powder (LP) and are found in Table 2 in equations [111] and [112], respectively.

${ }^{5} \mathrm{WP}=$ Whey protein.

Table 6. Changes in retention of milk to cheese attributable to different $\kappa$-CN milk protein genotypes (AA or $\mathrm{BB}$ ) from the literature ${ }^{1}$

\begin{tabular}{lllllll}
\hline Component & $\mathrm{AA}^{2}$ & $\mathrm{BB} 1^{2}$ & Average $1^{3}$ & $\mathrm{AA} 2^{4}$ & $\mathrm{BB} 2^{4}$ & ${\text { Average } 2^{5}}^{5}$ \\
\hline Protein & 0.749 & 0.756 & 0.7525 & 0.7601 & 0.7751 & 0.7676 \\
Fat & 0.915 & 0.921 & 0.9180 & 0.7795 & 0.8993 & 0.8394 \\
\hline
\end{tabular}

${ }^{1}$ Units in $\mathrm{kg}$ of component/kg of input.

${ }^{2}$ From Schaar (1985).

${ }^{3}$ Average of protein and fat retentions of AA1 and BB1 genotype values, from Schaar (1985).

${ }^{4}$ Walsh et al. (1995).

${ }^{5}$ Average of protein and fat retentions of AA2 and BB2 genotype values, from Walsh et al. (1995). 
Table 7. Fixed retentions of $\mathrm{CN}$ and fat to cheese attributable to different $\kappa$-CN milk protein genotypes used in model simulations ${ }^{1}$

\begin{tabular}{lll}
\hline Genotype $^{2}$ & $\begin{array}{l}\text { CN } \\
\text { retentions }\end{array}$ & $\begin{array}{l}\text { Fat } \\
\text { retentions }\end{array}$ \\
\hline AA protein (AA1P) & 0.7150 & 0.9180 \\
BB protein (BB1P) & 0.7220 & 0.9180 \\
Average 1 (AVG1) & 0.7185 & 0.9180 \\
AA protein (AA2P) & 0.7261 & 0.8394 \\
BB protein (BB2P) & 0.7411 & 0.8394 \\
Average 2 (AVG2) & 0.7336 & 0.8394 \\
AA fat (AA1F) & 0.7185 & 0.9150 \\
BB fat (BB1F) & 0.7185 & 0.9210 \\
AA fat (AA2F) & 0.7336 & 0.7795 \\
BB fat (BB2F) & 0.7336 & 0.8993 \\
\hline
\end{tabular}

${ }^{1}$ Units in $\mathrm{kg}$ of component $/ \mathrm{kg}$ of input using average values from Table 6 corrected for whey protein retention. Whey protein and ash retentions were fixed at 0.034 and 0.16 , respectively, for all genotypes. Water retentions were a minimum of 0 and a maximum of 1 , and lactose retentions were a minimum of 0.045 and a maximum of 0.05 for all genotypes.

${ }^{2} \mathrm{AA}$ and $\mathrm{BB}$ are $\kappa$-CN genotypes, 1 (e.g., $\mathrm{AA} 1 \mathrm{P}$ ) is based on protein and fat retentions from Schaar (1985), and 2 (e.g., AA2P) is based on protein and fat retentions from Walsh et al. (1995). For CN retentions: P (e.g., AA1P), AVE1 and AVE2 indicate the numbers are from Table 6 protein values corrected for whey protein and F (e.g., AA1F) indicates the numbers are averages of protein values AA1 and BB1 or AA2 and BB2 from Table 6 protein values corrected for whey protein. For fat retentions: P, AVE1, and AVE2 indicate the numbers are from averages of fat values $\mathrm{AA} 1$ and $\mathrm{BB} 1$ or $\mathrm{AA} 2$ and $\mathrm{BB} 2$ from Table 6 fat values and $\mathrm{F}$ indicates the numbers are from Table $6 \mathrm{fat}$ values. Numbers correspond to $\mathrm{CN}$ and fat retentions for MinCheese and MaxCheese ${ }_{I}$ as described in Table 2 in equations [6], [16], [24], [31], and [37], and in equations [7], [17], [25], [32], and [38], respectively.

tion of cheese, fat-reduced whey, and cream were not significantly different among the simulations and are not reported. A high-CN milk composition (4.33\% protein, $3.98 \%$ fat) resulted in significantly higher cheese yield, followed by a low-fat milk composition $(3.25 \%$ protein, $1.89 \%$ fat), which was not significant. A highfat milk composition $(3.25 \%$ protein, $5.97 \%$ fat) produced the lowest amount of cheese and the most cream sold. In simulations with a low-CN milk composition and low-whey protein milk composition including all genotypes, NDM was bought to increase CN input into the plant $(2,135$ and $444 \mathrm{~kg}$ of NDM bought, respectively).

Cream was bought in all simulations with low-fat milk compositions (3,350 kg of cream bought) and high$\mathrm{CN}$ milk compositions with genotype AA2F (CN retention of 0.7336 and fat retention of 0.7795$)$ (422 kg of cream bought) to increase the fat input into the plant. Cream was bought with the AA2F genotype and highCN milk composition because retentions were comparatively higher on $\mathrm{CN}$ and lower on fat. In simulations in which cream was bought, the fat-reduced whey sold was highest and cream was not sold. As a result, simulations in which cream was bought (low-cream milk compositions) resulted in the lowest profit. The high-CN milk composition resulted in significantly higher cheese and less cream sold (Table 8).

The high-fat milk composition produced the lowest amount of cheese and fat-reduced whey sold because fat was diverted to cream sold, resulting in the highest profit from any of the milk composition simulations (Table 8). Cream sold, fat-reduced whey sold, and cheese produced were dependent on the fat and CN input into the plant. However, overall profit was dependent on the fat content and fat retention in cheese because of the high price of cream. In general, the more cheese that was produced, the less cream was sold (Table 8).

Milk composition affected cheese production and profit more than did different retentions (genotypes; Tables 8 and 9). Changes in composition (Table 4) resulted in a 3,000-kg difference in cheese production and a $\$ 54,000$ difference in profit (Table 8). Changes in retentions (Table 7) resulted in a $970-\mathrm{kg}$ difference in cheese production and a $\$ 5,878$ difference in profit

Table 8. Inputs and products produced as predicted by model simulations of cheese making with different milk compositions ${ }^{1}$

\begin{tabular}{lllcr}
\hline Milk composition & Cheese, kg & FRWS, kg & CRS, kg & Profit, $\$$ \\
\hline Average 3.25\% protein & 7,442 & 82,382 & 4,329 & 44,274 \\
Low WP, 3.25\% protein & 7,940 & 82,460 & 3,953 & 44,237 \\
High WP, 3.25\% protein & 7,197 & 82,683 & 4,370 & 43,039 \\
Low CN & 7,344 & 83,877 & 4,318 & 40,710 \\
High CN & $9,846^{*}$ & $83,070^{*}$ & $2,223^{*}$ & 40,464 \\
Low WP & 7,440 & 82,556 & 4,295 & 44,187 \\
High WP & 7,444 & 82,171 & 4,370 & 44,378 \\
Low fat & 8,004 & $89,193^{*}$ & $0^{*}$ & $16,490^{*}$ \\
High fat & $6,834^{*}$ & $74,480^{*}$ & $11,781^{*}$ & $70,586^{*}$ \\
Low lactose & 7,471 & 84,052 & 4,113 & 44,058 \\
High lactose & 7,462 & 82,131 & 4,380 & 44,462 \\
SEM & 91 & 79 & 215 & 257 \\
\hline
\end{tabular}

${ }^{1}$ As described in Table 4 . FRWS $=$ fat-reduced whey sold; CRS = cream sold; WP = whey protein.

*Different from all other products produced or profits within a column $(P<0.006)$. 
Table 9. Inputs and products produced as predicted by model simulations of cheese making with different milk to cheese retentions ${ }^{1}$

\begin{tabular}{llllr}
\hline Retention & Cheese, kg & FRWS, kg & CRS, kg & Profit, \$ \\
\hline AA1P & 7,720 & 82,600 & 4,421 & 43,763 \\
BB1P & 7,748 & 82,603 & 4,985 & 43,827 \\
AVG1 & 7,734 & 82,602 & 4,415 & 43,795 \\
AA2P & 7,435 & 82,679 & 4,226 & 42,380 \\
BB2P & 7,509 & 82,703 & 4,179 & 42,444 \\
AVG2 & 7,470 & 82,690 & 4,204 & 42,416 \\
AA1F & 7,720 & 82,603 & 4,411 & 43,747 \\
BB1F & 7,747 & 82,601 & 4,419 & 43,843 \\
AA2F & 7,329 & 82,910 & 3,886 & $40,602^{*}$ \\
BB2F & 7,716 & 82,624 & 4,352 & 43,587 \\
SEM & 91 & 79 & 215 & 257 \\
\hline
\end{tabular}

${ }^{1}$ Symbols represent different genotype combinations of $\mathrm{CN}$ and fat retentions from Table 7 used in simulations. FRWS $=$ fat-reduced whey sold; CRS = cream sold.

*Different from all other profits $(P<0.0001)$.

(Table 9). The BB1P (CN retention of 0.7220 and fat retention of 0.9180 ) retention resulted in the most cheese produced and the most cream sold. The lowest amount of cheese produced, the most fat-reduced whey sold, the lowest cream sold, and the lowest profit were from the AA2F retention. Therefore, given the prices and compositions used in the simulations, the best genotypes for cheese production and profit were BB1F $(\mathrm{CN}$ retention of 0.7185 and fat retention of 0.9210 ) and BB1P. The BB1F profit was $\$ 48$ over AVG1 (CN retention of 0.7185 and fat retention of 0.9180 ) for 13 $\mathrm{kg}$ more cheese and the BB1P profit was $\$ 32$ over AVG1 for $14 \mathrm{~kg}$ more cheese.

Different milk composition-genotype combinations also resulted in different maximum prices that a processing plant would be willing to pay for NDM (as a $\mathrm{CN}$ source) and cream bought (as a fat source) to optimize profit from cheese and whey production. For the high-CN composition, the value of NDM was $\$ 0 / \mathrm{kg}$ across all genotypes (Table 10). However, for the low$\mathrm{CN}$ composition, the value of NDM averaged $\$ 2.13 / \mathrm{kg}$ across genotypes. For the AA2F genotype, the value of $\mathrm{NDM}$ was also $\$ 0 / \mathrm{kg}$ except for the low-CN and lowwhey protein (3.25\% protein) compositions. The overall average, excluding the high-CN composition row and the AA2F genotype column, was $\$ 1.50 / \mathrm{kg}$. The overall average value of cream bought was $\$ 1.38 / \mathrm{kg}$ (Table 11), excluding the low-fat composition row (average \$11.61/ $\mathrm{kg}$ ) and the high-CN milk composition-AA2F low-fatretention genotype $(\$ 83.73 / \mathrm{kg})$. The combination of high-CN milk composition and low-fat-retention genotype (AA2F) greatly increased the value of cream to the cheese plant.

Because of the high value of cream, the dried whey products (demineralized whey, $34 \%$ whey protein concentrate, and $80 \%$ whey protein concentrate) were not produced in the sensitivity analysis runs. However, when the selling prices were adjusted so that they would be produced, the price depended on the quantity of protein in the dried whey product and the quantity of protein in the milk. Tables 12 to 14 show the minimum selling prices for demineralized whey, $34 \%$ whey protein concentrate, and $80 \%$ whey protein concentrate, respectively. Eighty percent whey protein concentrate (at $\$ 57.62 / \mathrm{kg}$ ) was worth more, on average, followed by $34 \%$ whey protein concentrate (at $\$ 26.66 / \mathrm{kg}$ ) and then demineralized whey $(\$ 12.50 / \mathrm{kg})$. The high-whey protein, $3.25 \%$ total protein, and low-whey protein milk compositions, $2.92 \%$ total protein (Table 4), resulted in the highest average values for these 2 rows across genotypes for demineralized whey $(\$ 19.68 / \mathrm{kg}), 34 \%$ whey protein concentrate $(\$ 42.56 / \mathrm{kg})$, and $80 \%$ whey protein concentrate $(\$ 98.14 / \mathrm{kg})$. The low-CN composition, $2.36 \%$ total protein, resulted in the lowest average values across genotypes for demineralized whey $(\$ 9.58 /$ $\mathrm{kg})$ and $34 \%$ whey protein concentrate $(\$ 19.93 / \mathrm{kg})$, and low-whey protein, $3.25 \%$ total protein composition, resulted in the lowest average value across genotypes for $80 \%$ whey protein concentrate $(\$ 34.05 / \mathrm{kg})$. Genotype (retentions) had a small effect on the value of dried whey products within a given milk composition.

\section{DISCUSSION}

Based on results from the sensitivity analyses and determination of input and output values, milk composition had a much greater effect on cheese yield than did retention effects attributable to different $\kappa$-CN genotypes. Few data sets are available on the effects of $\kappa$-CN genotypes on retentions and milk composition. Data from only 2 studies were found and used to set protein and fat retentions in the model (Table 6). In both data sets, the AA genotype had consistently lower retention for protein and fat than did the BB genotype. Data from Walsh et al. (1995) showed a greater difference between $\mathrm{AA}$ and $\mathrm{BB}$ retentions than did data from Schaar (1985). As a result, retentions from Walsh et al. (1995) resulted in more cheese production from the BB genotype, compared with the AA genotype. Based on these data, the $\mathrm{BB}$ genotype protein retention effects resulted in $51 \mathrm{~kg}$ more cheese than did the AA genotype protein retentions, and the $\mathrm{BB}$ genotype fat-retention effects resulted in $207 \mathrm{~kg}$ more cheese than did the AA genotype fat retentions (Table 9 ). The $\kappa$-CN genotype may also affect milk composition; however, the data available were insufficient to quantify the effect when trimester and season of milk production were also considered. Sapru et al. (1997) examined the effects of stage of lactation and milking frequency on milk composition and Cheddar cheese yield. Using data from 100 cows, they found that the percentage of fat increased (3.50 to 
Table 10. Maximum prices $(\$ / \mathrm{kg})$ willing to pay for NDM to use in cheese processing for each milk composition ${ }^{1}$ and genotype combination $^{2}$

\begin{tabular}{|c|c|c|c|c|c|c|c|c|c|c|c|}
\hline \multirow[b]{2}{*}{ Milk composition } & \multicolumn{10}{|c|}{ Genotype } & \multirow[b]{2}{*}{ Average } \\
\hline & AA1P & $\mathrm{BB} 1 \mathrm{P}$ & AVG1 & $\mathrm{AA} 2 \mathrm{P}$ & $\mathrm{BB} 2 \mathrm{P}$ & AVG2 & $\mathrm{AA} 1 \mathrm{~F}$ & $\mathrm{BB} 1 \mathrm{~F}$ & $\mathrm{AA} 2 \mathrm{~F}$ & $\mathrm{BB} 2 \mathrm{~F}$ & \\
\hline Average $3.25 \%$ protein & 1.44 & 1.45 & 1.45 & 1.46 & 1.48 & 1.45 & 1.45 & 1.45 & 0 & 1.47 & 1.31 \\
\hline Low WP $3.25 \%$ protein & 2.15 & 2.16 & 2.15 & 2.08 & 1.48 & 1.47 & 2.15 & 2.16 & 1.47 & 2.17 & 1.94 \\
\hline High WP $3.25 \%$ protein & 1.44 & 1.45 & 1.45 & 0 & 0 & 0 & 1.45 & 1.45 & 0 & 0 & 0.72 \\
\hline Low $\mathrm{CN}$ & 2.14 & 2.17 & 2.15 & 2.08 & 2.12 & 2.10 & 2.15 & 2.16 & 2.01 & 2.17 & 2.13 \\
\hline High CN & 0 & 0 & 0 & 0 & 0 & 0 & 0 & 0 & 0 & 0 & 0.00 \\
\hline Low WP & 1.44 & 1.45 & 1.45 & 1.46 & 1.48 & 1.47 & 1.45 & 1.45 & 0 & 1.47 & 1.31 \\
\hline High WP & 1.46 & 1.47 & 1.46 & 1.47 & 1.49 & 1.48 & 1.46 & 1.46 & 0 & 1.48 & 1.32 \\
\hline Low fat & 1.44 & 1.45 & 1.45 & 1.46 & 1.48 & 1.47 & 1.45 & 1.45 & 0 & 1.47 & 1.31 \\
\hline High fat & 1.44 & 1.45 & 1.45 & 1.46 & 0 & 1.47 & 1.45 & 1.45 & 0 & 1.47 & 1.16 \\
\hline Low lactose & 1.44 & 1.45 & 1.45 & 1.46 & 1.48 & 1.47 & 1.45 & 1.45 & 0 & 1.47 & 1.31 \\
\hline High lactose & 1.44 & 1.45 & 1.45 & 1.46 & 1.48 & 1.47 & 1.45 & 1.45 & 0 & 1.47 & 1.31 \\
\hline
\end{tabular}

${ }^{1}$ See Table 4 .

${ }^{2}$ Symbols represent different genotype combinations of $\mathrm{CN}$ and fat retentions from Table 7 used in simulations. WP $=$ Whey protein.

${ }^{3}$ Average across columns.

3.70) and the percentage of $\mathrm{CN}$ increased (2.30 to 2.37) from early to late lactation. However, the percentages of fat and $\mathrm{CN}$ decreased from twice-a-day milking to thrice-a-day milking (3.58 to $3.50,2.40$ to 2.36 , respectively). Correspondingly, Cheddar cheese yield increased from early to late lactation by $0.59 \%$ and decreased by $0.20 \%$ with more frequent milking. However, none of the Cheddar cheese yield values were significantly different. Milk composition data used in the model were based on milk production records from the University of California-Davis dairy herd collected from 2000 to 2002 . Although the herd was genotyped for $\kappa$-CN, the time (3 yr) was insufficient to detect a significant difference in milk composition because of selection for $\kappa$-CN AA or BB in milk. The effect on cheese production of using milk from cows selected for the $\mathrm{BB} \kappa-\mathrm{CN}$ genotype could be tested more completely if more data were available on milk composition and cheese retentions with different milk protein genotypes.
The model showed that both the protein and fat contents of milk should be considered when selecting for the $\kappa$-CN BB genotype. Previous studies (Schaar, 1985; Walsh et al., 1995) showed that the $\kappa$-CN genotype affected both protein and fat retentions, which will affect cheese yield. The model quantified how differences in milk composition significantly affected cheese and whey yields (Table 9). Although $\mathrm{CN}$ was more important to cheese yield, both fat and CN contents determined the yield, as illustrated by the Van Slyke formula (Lucey and Kelly, 1994; Covington, 1998). Casein was important to cheese yield because it influenced rennet coagulation by way of forming the structural matrix of cheese, which influenced the retention of fat and moisture (Lucey and Kelly, 1994).

Estimated maximum prices for NDM and cream bought (Tables 10 and 11), minimum prices for dried whey products (demineralized whey, $34 \%$ whey protein concentrate, and $80 \%$ whey protein concentrate in Ta-

Table 11. Maximum prices $(\$ / \mathrm{kg})$ willing to pay for cream bought to use in a cheese-processing plant for each milk composition ${ }^{1}$ and genotype combination $^{2}$

\begin{tabular}{|c|c|c|c|c|c|c|c|c|c|c|c|}
\hline \multirow[b]{2}{*}{ Milk composition } & \multicolumn{10}{|c|}{ Genotype } & \multirow[b]{2}{*}{ Average $^{3}$} \\
\hline & AA1P & BB1P & AVG1 & $\mathrm{AA} 2 \mathrm{P}$ & $\mathrm{BB} 2 \mathrm{P}$ & AVG2 & $\mathrm{AA} 1 \mathrm{~F}$ & $\mathrm{BB} 1 \mathrm{~F}$ & $\mathrm{AA} 2 \mathrm{~F}$ & $\mathrm{BB} 2 \mathrm{~F}$ & \\
\hline Average $3.25 \%$ protein & 1.39 & 1.40 & 1.40 & 1.32 & 1.34 & 1.33 & 1.39 & 1.40 & 1.26 & 1.40 & 1.36 \\
\hline Low WP $3.25 \%$ protein & 1.39 & 1.40 & 1.40 & 1.32 & 1.34 & 1.33 & 1.39 & 1.40 & 1.26 & 1.40 & 1.36 \\
\hline High WP $3.25 \%$ protein & 1.39 & 1.40 & 1.40 & 1.32 & 1.34 & 1.33 & 1.39 & 1.40 & 1.50 & 1.40 & 1.39 \\
\hline Low CN & 1.39 & 1.40 & 1.40 & 1.32 & 1.34 & 1.33 & 1.39 & 1.40 & 1.26 & 1.40 & 1.36 \\
\hline High CN & 1.70 & 1.70 & 1.70 & 1.58 & 1.59 & 1.58 & 1.69 & 1.70 & 83.73 & 1.67 & 9.86 \\
\hline Low WP & 1.39 & 1.40 & 1.40 & 1.33 & 1.34 & 1.33 & 1.39 & 1.40 & 1.26 & 1.40 & 1.36 \\
\hline High WP & 1.40 & 1.41 & 1.41 & 1.34 & 1.35 & 1.34 & 1.40 & 1.41 & 1.27 & 1.41 & 1.37 \\
\hline Low fat & 13.53 & 13.17 & 13.37 & 9.80 & 9.65 & 9.80 & 13.19 & 13.49 & 8.24 & 11.82 & 11.61 \\
\hline High fat & 1.29 & 1.30 & 1.30 & 1.24 & 1.25 & 1.24 & 1.29 & 1.30 & 1.18 & 1.30 & 1.27 \\
\hline Low lactose & 1.39 & 1.40 & 1.40 & 1.33 & 1.34 & 1.33 & 1.39 & 1.40 & 1.26 & 1.40 & 1.36 \\
\hline High lactose & 1.39 & 1.40 & 1.40 & 1.33 & 1.34 & 1.33 & 1.39 & 1.40 & 1.26 & 1.40 & 1.36 \\
\hline
\end{tabular}

${ }^{1}$ See Table 4.

${ }^{2}$ Symbols represent different genotype combinations of $\mathrm{CN}$ and fat retentions from Table 7 used in simulations. WP $=$ Whey protein.

${ }^{3}$ Average across columns. 
Table 12. Minimum prices $(\$ / \mathrm{kg})$ willing to sell demineralized whey produced from a cheese-processing plant for each milk composition ${ }^{1}$ and genotype combination ${ }^{2}$

\begin{tabular}{|c|c|c|c|c|c|c|c|c|c|c|c|}
\hline Milk composition & \multicolumn{10}{|c|}{ Genotype } & Average $^{3}$ \\
\hline Average $3.25 \%$ protein & 11.48 & 11.48 & 11.48 & 10.98 & 11.48 & 11.48 & 11.48 & 11.48 & 11.47 & 11.48 & 11.43 \\
\hline High WP $3.25 \%$ protein & 19.63 & 19.63 & 19.63 & 19.55 & 19.53 & 19.54 & 19.61 & 19.64 & 19.45 & 19.62 & 19.58 \\
\hline Low CN & 9.70 & 9.71 & 6.99 & 9.83 & 10.10 & 10.05 & 9.70 & 9.70 & 10.28 & 9.73 & 9.58 \\
\hline High CN & 11.26 & 11.26 & 11.26 & 11.26 & 11.26 & 11.26 & 11.26 & 11.26 & 11.26 & 11.26 & 11.26 \\
\hline High fat & 10.98 & 10.96 & 10.99 & 10.97 & 10.99 & 10.99 & 10.99 & 10.98 & 10.99 & 10.99 & 10.98 \\
\hline Low lactose & 12.12 & 12.12 & 12.12 & 12.11 & 12.11 & 12.11 & 12.11 & 12.11 & 12.11 & 12.11 & 12.11 \\
\hline High lactose & 11.26 & 11.26 & 11.26 & 11.26 & 11.25 & 11.26 & 11.26 & 11.26 & 11.26 & 11.26 & 11.26 \\
\hline
\end{tabular}

${ }^{1}$ See Table 4.

${ }^{2}$ Symbols represent different genotype combinations of $\mathrm{CN}$ and fat retentions from Table 7 used in simulations. WP $=$ Whey protein.

${ }^{3}$ Average across columns.

bles 12 to 14), and the dollar contributions of milk composition and genotype to cheese yield and profit (Tables 8 and 9) were based on current market prices as of March 2004 (Table 1). Unfortunately, the price of cream was very high relative to other inputs and products, thus making it difficult to directly assess the value of milk composition and genotype on dried whey products. The only products that were profitable to produce were cheese, fat-reduced whey sold, and cream sold. Virtually no dried whey products were produced. If the price of cream had been lower, more products would have been produced (Craig et al., 1989). Therefore, many simulations were run, with the costs of NDM and cream bought adjusted to find the maximum price the plant would be willing to pay for more protein and fat, respectively, and the minimum selling price for demineralized whey, $34 \%$ whey protein concentrate, and $80 \%$ whey protein concentrate. Comparing market prices used (Table 1) to the value of purchased inputs to the plant estimated by the model (Tables 10 and 11) revealed that NDM was overpriced at $\$ 1.77 / \mathrm{kg}$ market and needed to be reduced to $\$ 1.50 / \mathrm{kg}$, based on the estimated model value (average of Table 10 excluding the $\mathrm{CN}$ composition row and the AA2F genotype column). Cream bought was also overpriced at $\$ 4.16 / \mathrm{kg}$ market and needed to be reduced to $\$ 1.38 / \mathrm{kg}$, based on estimated model value (average of Table 11 excluding the low-fat composition row and the high-CN composition-AA2F genotype value). Similarly, demineralized whey was underpriced at $\$ 1.25 / \mathrm{kg}$ market (Table 1) and needed to be increased to $\$ 12.50 / \mathrm{kg}$, based on the estimated model value (average of Table 12); $34 \%$ whey protein concentrate was underpriced at $\$ 1.61 / \mathrm{kg}$ market and need to be increased to $\$ 26.66 / \mathrm{kg}$, based on the estimated model value (average of Table 13); and $80 \%$ whey protein concentrate was underpriced at $\$ 4.74 / \mathrm{kg}$ mar-

Table 13. Minimum prices $(\$ / \mathrm{kg})$ willing to sell $34 \%$ whey protein concentrate produced from a cheese-processing plant for each milk composition $^{1}$ and genotype combination ${ }^{2}$

\begin{tabular}{|c|c|c|c|c|c|c|c|c|c|c|c|}
\hline \multirow[b]{2}{*}{ Milk composition } & \multicolumn{10}{|c|}{ Genotype } & \multirow[b]{2}{*}{ Average $^{3}$} \\
\hline & AA1P & BB1P & AVG1 & $\mathrm{AA} 2 \mathrm{P}$ & $\mathrm{BB} 2 \mathrm{P}$ & AVG2 & $\mathrm{AA} 1 \mathrm{~F}$ & $\mathrm{BB} 1 \mathrm{~F}$ & $\mathrm{AA} 2 \mathrm{~F}$ & $\mathrm{BB} 2 \mathrm{~F}$ & \\
\hline Average $3.25 \%$ protein & 23.90 & 23.09 & 23.89 & 23.78 & 23.90 & 23.90 & 23.90 & 23.90 & 23.90 & 23.90 & 23.81 \\
\hline Low WP $3.25 \%$ protein & 21.03 & 21.21 & 21.11 & 23.06 & 23.26 & 23.26 & 21.17 & 21.06 & 23.26 & 21.90 & 22.03 \\
\hline High WP $3.25 \%$ protein & 42.43 & 42.43 & 42.44 & 42.26 & 42.21 & 42.23 & 42.39 & 42.45 & 42.03 & 42.40 & 42.33 \\
\hline Low CN & 19.20 & 19.32 & 19.06 & 20.46 & 20.77 & 20.65 & 19.29 & 19.21 & 21.57 & 19.74 & 19.93 \\
\hline High CN & 23.39 & 23.39 & 23.39 & 23.39 & 23.39 & 23.39 & 23.39 & 23.39 & 23.39 & 23.39 & 23.39 \\
\hline Low WP & 42.83 & 42.76 & 42.81 & 42.80 & 42.81 & 42.81 & 42.76 & 42.83 & 42.74 & 42.76 & 42.79 \\
\hline High WP & 23.14 & 23.14 & 23.14 & 23.09 & 23.14 & 23.15 & 23.14 & 23.14 & 23.14 & 23.09 & 23.13 \\
\hline Low fat & 24.53 & 24.52 & 24.52 & 24.52 & 24.53 & 24.52 & 24.52 & 24.52 & 24.53 & 24.53 & 24.52 \\
\hline High fat & 22.78 & 22.76 & 22.79 & 22.74 & 22.79 & 22.78 & 22.78 & 22.76 & 22.79 & 22.79 & 22.78 \\
\hline Low lactose & 25.18 & 25.18 & 25.18 & 25.16 & 25.17 & 25.16 & 25.17 & 25.17 & 25.18 & 25.18 & 25.17 \\
\hline High lactose & 23.39 & 23.40 & 23.39 & 23.40 & 23.35 & 23.39 & 23.39 & 23.39 & 23.40 & 23.39 & 23.39 \\
\hline
\end{tabular}

${ }^{1}$ See Table 4.

${ }^{2}$ Symbols represent different genotype combinations of $\mathrm{CN}$ and fat retentions from Table 7 used in simulations. WP $=$ Whey protein.

${ }^{3}$ Average across columns. 
Table 14. Minimum prices $(\$ / \mathrm{kg})$ willing to sell $80 \%$ whey protein concentrate produced from a cheese-processing plant for each milk composition $^{1}$ and genotype combination ${ }^{2}$

\begin{tabular}{|c|c|c|c|c|c|c|c|c|c|c|c|}
\hline Milk composition & \multicolumn{10}{|c|}{ Genotype } & Average \\
\hline Average $3.25 \%$ protein & 54.08 & 54.09 & 54.05 & 54.05 & 53.78 & 54.08 & 54.08 & 54.08 & 54.03 & 54.08 & 54.04 \\
\hline High WP $3.25 \%$ protein & 97.83 & 97.84 & 97.85 & 97.43 & 97.32 & 97.38 & 97.85 & 97.89 & 96.89 & 97.78 & 97.61 \\
\hline Low CN & 43.00 & 43.31 & 42.70 & 46.09 & 46.72 & 46.42 & 43.23 & 43.05 & 48.65 & 44.30 & 44.75 \\
\hline High CN & 52.89 & 52.89 & 52.90 & 52.91 & 52.92 & 52.91 & 52.90 & 52.89 & 52.93 & 52.91 & 52.91 \\
\hline Low WP & 98.77 & 98.61 & 98.77 & 98.72 & 98.73 & 98.71 & 98.60 & 98.77 & 98.58 & 98.50 & 98.68 \\
\hline High fat & 51.36 & 51.30 & 51.46 & 51.35 & 51.45 & 51.44 & 51.46 & 51.30 & 51.47 & 51.46 & 51.41 \\
\hline Low lactose & 57.10 & 57.10 & 57.10 & 57.05 & 57.07 & 57.07 & 57.08 & 57.07 & 57.09 & 57.08 & 57.08 \\
\hline High lactose & 52.92 & 52.90 & 52.88 & 52.90 & 52.81 & 52.87 & 52.88 & 52.88 & 52.90 & 52.88 & 52.88 \\
\hline
\end{tabular}

${ }^{1}$ See Table 4.

${ }^{2}$ Symbols represent different genotype combinations of $\mathrm{CN}$ and fat retentions from Table 7 used in simulations. WP $=$ Whey protein.

${ }^{3}$ Average across columns.

ket and needed to be increased to $\$ 57.62 / \mathrm{kg}$, based on the estimated model value (average of Table 14). Different market prices would result in different values for the 2 inputs and 3 products.

Other models have been developed for improving cheese plant production and efficiency. The Van Slyke equation is the best known and most widely used (Covington, 1998). The Van Slyke equation predicts cheese yield based on the percentages of protein, fat, and moisture. The Van Slyke equation has been incorporated into other mass balance linear programming models to specifically address the standardization of milk inputs to obtain a consistent product. A linear mass balance optimization model by Kerrigan and Norback (1986) examined the results of using different types of objectives functions: to maximize net returns, to maximize cheese yield, or to minimize cost. Craig et al. (1989) built on the model developed by Kerrigan and Norback (1986) to maximize net returns from natural cheese and the use of intermediate products (cheese, whey cream, and separated whey) from cheese making to make processed cheese products. But in both models, they did not consider components other than protein, fat, and moisture, the impact of different milk compositions on cheese making, and the use of retentions to formulate intermediates and products to evaluate genotype or component differences or the production of dried whey products. Papadatos et al. (2002) developed an optimization mass balance model maximizing net revenue in cheese making and examined changes in milk price and milk composition on Cheddar cheese and low-moisture part-skim Mozzarella. The model was similar to models by Kerrigan and Norback (1986) and Craig et al. (1989) because they used an equation such as the Van Slyke equation or Barbano (Papadatos et al., 2002) to estimate cheese yield instead of retentions. Unlike previous models, however, products such as whey protein concentrates, whey powder, and lactose powder were included in the model reported here. The current model provides a structure that allows retention data on individual input compositions to be evaluated in an optimization format.

\section{CONCLUSIONS}

The model developed is unique in its ability to track the components of milk and other purchased inputs and to estimate yields through the retentions of components. The results demonstrated that milk composition has a greater effect on Cheddar cheese production and profit than does genotype. The model estimated that a high-CN milk composition (3.57\%) would result in the greatest cheese yield $(9,846 \mathrm{~kg} / 100,000 \mathrm{~kg}$ of milk) but that a high-fat milk composition $(5.97 \%)$ would result in the greatest profit $(\$ 70,586 / 100,000 \mathrm{~kg}$ of milk). The $\mathrm{AA}$ and $\mathrm{BB} \kappa$-CN genotypes were assumed to primarily affect the retention of milk components in cheese. Although the $\kappa$-CN B allele has been associated with increased Cheddar cheese yield, the model estimated that the increased cheese yield was not significantly different between the $\mathrm{AA}$ and $\mathrm{BB} \kappa$-CN genotypes and would not significantly increase profit. Therefore, a cheese plant would not benefit from encouraging dairy producers to select for bulls with the B $\kappa$-CN allele at the prices and retentions examined using the model. More data on how milk expressing the B variant of $\kappa$-CN affects retentions, cheese yield, or both may change these results.

The model provides managers of a cheese plant with the ability to optimize component use, maximize profit, and assess cheese production data and efficiency. With a trend toward increased whey by-product processing 
and utilization, the model will be of benefit for setting prices on several whey products in integrated plants.

\section{ACKNOWLEDGMENTS}

The authors appreciate the input and advice from personnel at Hilmar Cheese Company (Hilmar, CA). The authors would like to thank K. Alamo from Silliker, Inc. (Modesto, CA) for milk compositional analyses. Research was partially supported by funding from the California Dairy Research Foundation (Davis, CA) through the Dairy Milk Components Laboratory at the University of California-Davis.

\section{REFERENCES}

Aleandri, R., L. G. Buttazzoni, J. C. Schneider, A. Caroli, and R. Davoli. 1990. The effects of milk protein polymorphisms on milk components and cheese-producing ability. J. Dairy Sci. 73:241255.

AOAC. 2002. Official Methods for Analysis of AOAC International. 17th ed. AOAC, Gaithersburg, MD.

Brooke, A., D. Kendrick, A. Meeraus, and R. Raman. 1998. GAMS: A User's Guide. Release 2.50. The Scientific Press, Redwood City, CA.

CDFA (California Department of Food and Agriculture). 1998. Announcement of March-May AA butter price, Table 15. June 19, 1998. CDFA, Sacramento, CA.

CDFA (California Department of Food and Agriculture). 2004. Announcement of minimum prices for classes $4 \mathrm{a}$ and $4 \mathrm{~b}$ market milk FOB processing plant. March 1, 2004. CDFA, Sacramento, CA.

Chandan, R. 1997. Dairy-Based Ingredients. Egan Press, St. Paul, $\mathrm{MN}$.

Covington, C. 1998. Predicting cheese yields. World Jersey Bull. (Apr. 1):8-9.

Craig, K. L., J. P. Norback, and M. E. Johnson. 1989. A linear programming model integrating resource allocation and product acceptability for processed cheese products. J. Dairy Sci. 72:3098-3108.

Feagan, J. T. 1979. Factors affecting protein composition of milk and their significance to dairy processing. Aust. J. Dairy Technol. $34: 77-81$.
US Department of Health and Human Services, FDA (U.S. Food and Drug Administration). 1998. Cheeses and Related Cheese Products. Pages 294-346 in Code of Federal Regulations, Title 21, Part 33. U.S. Government Printing Office, Washington, DC.

Kerrigan, G. L., and J. P. Norback. 1986. Linear programming in the allocation of milk resources for cheese making. J. Dairy Sci. 69:1432-1440.

Lucey, J., and J. Kelly. 1994. Cheese yield. J. Soc. Dairy Technol 47:1-14.

Marziali, A. S., and K. F. Ng-Kwai-Hang. 1986. Relationships between milk protein polymorphisms and cheese yielding capacity. J. Dairy Sci. 69:1193-1201.

Ng-Kwai-Hang, K. F. 1993. Association between genetic polymorphism of milk proteins and production traits during three lactations. J. Dairy Sci. 73:3414-3420.

Papadatos, A., A. M. Berger, J. E. Pratt, and D. M. Barbano. 2002. A nonlinear programming optimization model to maximize net revenue in cheesemaking. J. Dairy Sci. 85:2768-2785.

Sapru, A., D. M. Barbano, J. J. Yun, L. R. Klei, P. A. Oltenacu, and D. K. Bandler. 1997. Cheddar cheese: Influence of milking frequency and stage of lactation on composition and yield. J. Dairy Sci. 80:437-446.

SAS Institute. 2002. Statistical Analysis System v. 8.1. SAS Inst. Inc., Cary, NC.

Schaar, J. 1985. Effects of genetic variants of $\kappa$-casein and $\beta$-lactoglobulin on cheesemaking. J. Dairy Res. 52:429-437.

Tong, P. S., S. Vink, N. Y. Farkye, and J. F. Medrano. 1994. Effect of genetic variants of milk proteins on the yield of cheddar cheese. Cheese yield and factors allocating its control. Pages 179-187 in Proc. Int. Dairy Federation Sem. Int. Dairy Federation, Brussels, Belgium.

USDA (United States Department of Agriculture). 2000. November 27-December 1, 2000, Average. Report 48. Vol. 67. USDA, Washington, DC.

USDA (United States Department of Agriculture). 2004. MD DA210: East fluid milk and cream review. Report 10. March 10, 2004. USDA, Washington, DC.

Walsh, C. D., T. Guinee, D. Harrington, R. Mehra, J. Murphy, J. F. Connolly, and R. J. Fitzgerald. 1995. Cheddar cheese making and rennet coagulation characteristics of bovine milks containing $\kappa$ casein AA or BB genetic variants. Milchwissenschaft 50:492-496.

Wong, N. P. 1988. Fundamentals of Dairy Chemistry. Van Nostrand Reinhold, New York, NY.

Zadow, J. G. 1992. Whey and Lactose Processing. Elsevier Applied Science, London, UK. 